\title{
ANALISIS KINERJA KEUANGAN PADA PT BANK MUAMALAT INDONESIA TBK
}

\author{
Ihsan Rambe \\ ihsanrambe@yahoo.co.id \\ Program Studi Akuntansi, Fakultas Ekonomi dan Bisnis, Universitas \\ Muhammadiyah Sumatera Utara
}

\begin{abstract}
The Indonesian economy was hit several times by the economic crisis. The collapse of the economy since then has led to a decline in public confidence in banks. At that time, there was one bank operating with sharia principles, namely Bank Muamalat Indonesia and it was not affected by the economic crisis. The existence of Muamalat Bank as a pioneer in establishing Islamic banking in Indonesia certainly deserves to be assessed the health of its financial performance. The Bank's financial performance refers to an assessment of the Bank's soundness. Bank health is in the interest of all related parties, both owners, managers (management), and the public who use the bank's services (Regulation of the Financial Services Authority Number 8 / POJK.03 / 2014). The data used in this study includes annual financial data published by PT. Bank Muamalat Indonesia Tbk from 2016 to 2018. The data analysis technique used in this study uses CAMEL analysis. The financial performance conditions at PT Bank Muamalat Tbk are in different circumstances but the most worrying is the profitability of the ROA and BOPO ratios in an unhealthy condition.
\end{abstract}

Keywords: Sharia Bank, Bank Health, Financial Performance

\begin{abstract}
Abstrak
Perekonomian Indonesia beberapa kali terkena krisis ekonomi. Jatuhnya perekonomian sejak saat itu menyebabkan merosotnya kepercayaan masyarakat terhadap perbankan. Saat itu, terdapat satu bank yang beroperasi dengan prinsip syariah yaitu Bank Muamalat Indonesia dan tidak terkena dampak krisis ekonomi. Eksistensi Bank Muamalat sebagai pelopor pendirian perbankan syariah di Indonesia tentu saja patut dinilai kesehatan kinerja keuangannya. Kinerja keuangan Bank merujuk pada penilaian tingkat kesehatan Bank. Kesehatan Bank menjadi kepentingan semua pihak terkait, baik pemilik, pengelola (manajemen), dan masyarakat pengguna jasa bank (Peraturan Otoritas Jasa Keuangan Nomor 8/P0JK.03/2014). Data yang digunakan dalam penelitian ini meliputi data keuangan tahunan yang dipublikasikan PT. Bank Muamalat Indonesia Tbk dari tahun 2016 sampai 2018. Teknik analisis data yang digunakan dalam penelitian ini menggunakan analisis CAMEL. Kondisi kinerja keuangan pada PT Bank Muamalat Tbk dalam keadaan yang berbeda-beda namun yang paling mengkhawatirkan pada rentabilitas rasio ROA dan BOPO dalam kondisi kurang sehat.
\end{abstract}

Kata Kunci : Bank Syariah, Kesehatan Bank, Kinerja Keuangan

\section{PENDAHULUAN}

Bank merupakan salah satu lembaga keuangan yang memiliki peranan penting bagi perekonomian suatu negara. Perbankan di Indonesia memiliki dua sistem yaitu 
perbankan dengan sistem konvensional dan perbankan dengan sistem syariah. Kinerja keuangan oleh lembaga keuangan perbankan syariah sangat penting untuk menciptakan industri perbankan syariah yang kuat sehingga dapat membantu peningkatan perekonomian sektor riil.

Perekonomian Indonesia beberapa kali terkena krisis ekonomi. Salah satunya yang sangat parah yakni pada pertengahan 1997 sampai 1998. Hal ini ditunjukkan oleh perubahan yang sangat tajam antara lain kenaikan tingkat suku bunga Sertifikat Bank Indonesia (SBI) dari 10,5 persen pada Juni 1997 menjadi 70,8 persen pada Juli 1998.

Selain itu, nilai tukar rupiah mengalami depresiasi secara signifikan dari Rp2.600 per US\$ 1 pada Januari 1997 menjadi Rp16.950 per US\$ 1 pada Juni 1998. Tentu saja pertumbuhan ekonomi pun demikian. Berdasarkan data statistik moneter, di akhir 1997 pertumbuhan ekonomi seberas 4,70 persen lalu menurun drastis pada angka minus 3,02 persen pada 1998. (Sugema, 2004)

Jatuhnya perekonomian sejak saat itu menyebabkan merosotnya kepercayaan masyarakat terhadap perbankan. Peristiwa krisis ekonomi telah menyita perhatian publik dan mengupayakan solusi untuk keluar dari krisis. Saat itu, terdapat satu bank yang beroperasi dengan prinsip syariah yaitu Bank Muamalat Indonesia dan tidak terkena dampak krisis ekonomi.

Hal tersebut menyebabkan para pakar ekonomi melirik eksistensi bank syariah dan menjadikan pemerintah mulai memperhatikan keberadaan bank syariah. Hal itu ditandai dengan dikeluarkannya UU Nomor 10 tahun 1998 tentang perbankan syariah yang memberikan kesempatan untuk mendirikan suatu bank dengan sistem bagi hasil.

Menurut Undang-undang Nomor 10 Tahun 1998 Pasal 1 Ayat 3, Bank Umum atau Konvensional adalah bank yang melaksanakan kegiatan usaha secara konvensional yang dalam kegiatannya memberikan jasa dalam lalu lintas pembayaran, sedangkan, Bank Syariah adalah bank yang menjalankan kegiatan usahanya berdasarkan prinsip syariah dan menurut jenisnya terdiri atas Bank Umum Syariah dan Bank Pembiayaan Rakyat Syariah (Undang-undang Nomor 21 Tahun 2008 Pasal 1 Ayat 7).

Karakteristik sistem perbankan syariah beroperasi berdasarkan prinsip bagi hasil memberikan alternatif sistem perbankan yang saling menguntungkan bagi masyarakat dan bank serta menonjolkan aspek keadilan dalam bertransaksi, investasi yang 
beretika, mengedepankan nilai-nilai kebersamaan dan persaudaraan dalam berproduksi, dan menghindari kegiatan spekulatif dalam transaksi keuangan.

Didirikan sejak 1 November 1991 dan resmi beroperasi pada 1 Mei 1992 bertahan hingga sekarang bukanlah hal yang mudah. Eksistensi Bank Muamalat yang dikenal sebagai pelopor pendirian perbankan syariah di Indonesia tentu saja patut dinilai kesehatan kinerja keuangannya.

Banyaknya perbankan syariah yang bermunculan saat ini yang berasal dari perbankan konvensional melalui unit usaha syariah yang kemudian berdiri sendiri menjadi bank umum syariah tentu saja memberikan penawaran yang berbeda-beda pada masyarakat sebagai nasabah atau sebagai investor.

Banyaknya perbankan syariah ini menjadikan Bank Muamalat harus senantiasa mempertahankan jati dirinya sebagai bank syariah pertama di Indonesia dan tahan terhadap terpaan krisis moneter, namun kini bertambah dengan banyaknya persaingan dengan bank syariah lainnya.

Langkah strategis yang dapat ditempuh dalam rangka memenangkan persaingan salah satunya ialah dengan cara meningkatkan kinerja keuangan. Peningkatan kinerja keuangan memiliki dampak sebagai usaha menjaga kepercayaan nasabah agar tetap setia menggunakan jasanya. Semakin baik kinerja keuangan maka semakin baik pula tingkat kesehatan bank tersebut.

Kinerja keuangan Bank merujuk pada penilaian tingkat kesehatan Bank. Kesehatan Bank menjadi kepentingan semua pihak terkait, baik pemilik, pengelola (manajemen), dan masyarakat pengguna jasa bank (Peraturan Otoritas Jasa Keuangan Nomor 8/P0JK.03/2014). Kesehatan bank diartikan sebagai kemampuan suatu bank untuk melakukan kegiatan operasional perbankan secara normal dan mampu memenuhi kewajibannya dengan baik dengan cara-cara yang sesuai dengan peraturan perbankan yang berlaku.

Diantara analisis yang digunakan untuk mengukur kinerja suatu bank adalah rasio permodalan, rasio kualitas aktiva, rasio rentabilitas, dan rasio likuiditas. Berdasarkan ikhtisar keuangan dari laporan tahunan PT Bank Muamalat Indonesia Tbk, diketahui bahwa total aset bergerak secara fluktuatif pada 3 tahun terakhir.

Pada tahun 2016 total aset sebesar Rp55.786.000.000.000;, pada tahun 2017 total aset sebesar Rp61.697.000.000.000; dan pada tahun 2018 total aset sebesar Rp57.227.000.000.000; oleh karena itu penelitian tentang “Analisis Kinerja Keuangan 
Pada PT Bank Muamalat Indonesia Tbk" perlu untuk dilakukan berkaitan dengan penilaian kesehatan bank.

Adapun penelitian terdahulu yang telah dilakukan oleh Marlyana dan Wirando (2018) dengan judul Analisa Tingkat Kesehatan Bank Syariah menghasilkan sebuah penelitian bahwa secara umum kinerja keuangan bank syariah tahun 2012-2016 adalah sehat bahkan beberapa sangat sehat untuk penelitian selanjutnya dapat mengikutsertakan faktor Good Corporate Governance (GCG) dengan menyebarkan kuisioner.

Penelitian oleh Kusumo (2008) dengan judul Analisis Kinerja Keuangan Bank Syariah Mandiri Periode 2002-2007 (Dengan Pendekatan PBI No.9/1/PBI/2007) yang memberikan hasil dilihat dari keseluruhan rasio keuangan selama enam periode pengamatan ini mencerminkan bahwa kondisi keuangan BSM tergolong baik dalam mendukung perkembangan usaha dan mengantisipasi perubahan kondisi perekonomian dan industri keuangan.

Serta BSM memiliki kemampuan keuangan yang memadai dalam mendukung rencana pengembangan usaha dan pengendalian resiko apabila terjadi perubahan yang signifikan pada industri perbankan. Penelitian lain yang dilakukan oleh Arnita Sari (2018)dengan judul Analisis Kinerja Keuangan Bank Syariah (Studi Kasus PT Bank Syariah Mandiri, Tbk tahun 2015-2017) yang memberikan hasil Hasil analisis nilai CAMEL secara keseluruhan pada Bank Syariah Mandiri pada tahun 2015 sebesar 83,44\%, pada tahun 2016 sebesar 84,68\%, dan pada tahun 2017 sebesar 86,44\% yang membuktikan bahwa Bank Syariah Mandiri dikategorikan sehat.

\section{KAJIAN TEORI}

\section{a. Laporan Keuangan}

Laporan keuangan terdiri dari neraca dan suatu perhitungan laba-rugi serta laporan mengenai perubahan ekuitas. Neraca tersebut menunjukkan atau menggambarkan jumlah suatu aset, kewajiban dan juga mengenai ekuitas dari suatu perusahaan pada tanggal tertentu (Munawir, 2010:5). Laporan keuangan adalah laporan yang menunjukkan kondisi keuangan perusahaan pada saat ini atau dalam suatu periode tertentu (Kasmir, 2008:7). Pada awalnya laporan keuangan bagi suatu perusahaan hanyalah berfungsi sebagai "alat pengujian" dari pekerjaan fungsi bagian pembukuan, akan tetapi untuk selanjutnya seiring dengan perkembangan jaman, fungsi 
laporan keuangan sebagai dasar untuk dapat menentukan atau melakukan penilaian atas posisi keuangan perusahaan tersebut.

Ikatan Akuntan Indonesia (2012:5) mengemukakan pengertian laporan keuangan yaitu: Laporan keuangan merupakan struktur yang menyajikan posisi keuangan dan kinerja keuangan dalam sebuah entitas. Tujuan umum dari laporan keuangan ini untuk kepentingan umum adalah penyajian informasi mengenai posisi keuangan (financial position), kinerja keuangan (financial performance), dan arus kas (cash flow) dari entitas yang sangat berguna untuk membuat keputusan ekonomis bagi para penggunanya.

Untuk dapat mencapai tujuan ini, laporan keuangan menyediakan informasi mengenai elemen dari entitas yang terdiri dari asset, kewajiban, network, beban dan pendapatan (termasuk gain dan loss), perubahan ekuitas dan arus kas. Informasi tersebut diikuti dengan catatan, akan membantu pengguna memprediksi arus kas masa depan.

\section{b. Analisis Rasio Keuangan}

Rasio merupakan alat ukur yang digunakan perusahaan untuk menganalisis laporan keuangan. Rasio menggambarkan suatu hubungan atau pertimbangan antara suatu jumlah tertentu dengan jumlah yang lain. Rasio keuangan merupakan indeks yang menghubungkan dua angka akuntansi dan diperoleh dengan membagi satu angka dengan angka lainnya (Kasmir, 2008:104).

Analisis rasio keuangan adalah analisa hubungan dari berbagai pos dalam berbagai laporan keuangan yang merupakan dasar untuk dapat menginterprestasikan kondisi keuangan dan hasil operasi suatu perusahaan (Munawir,2001:64). Analisis Rasio keuangan meliputi rasio permodalan, aktiva produktif, rentabilitas, likuiditas dan kepatuhan (compliance) (Taswan,2010:164).

Dalam menggunakan analisis rasio keuangan pada dasarnya dapat melakukannya dengan dua macam perbandingan, yaitu: membandingkan rasio sekarang (present ratio) dengan rasio-rasio dari waktu yang telah lalu (histories ratio) atau dengan rasio-rasio yang diperkirakan untuk waktu yang akan datang dari perusahaan yang sama dan membandingkan rasio-rasio dari suatu perusahaan dengan rasio-rasio sejenis dari perusahaan yang lain yang sejenis. 
Untuk menilai kesehatan suatu bank dapat diukur dengan berbagai metode. Salah satu alat untuk mengukur kesehatan bank adalah dengan analisis CAMEL. Unsurunsur dalam analisis CAMEL adalah sebagai berikut :

\section{a) Capital (Permodalan)}

Capital adalah uang atau harta benda (barang, pabrik, kantor dan sebagainya) yang dipakai untuk menjalankan suatu usaha untuk mencari keuntungan, menambah kekayaan dan lain-lain (Winarno dan Ismaya, 2003:32). Penilaian didasarkan kepada permodalan yang dimiliki oleh salah satu bank. Salah satu penilaian adalah dengan metode CAR (Capital Adequacy Ratio), yaitu dengan cara membandingkan modal terhadap aktiva tertimbang menurut risiko (ATMR) (Kasmir, 2014:300).

Besarnya nilai Capital Adequacy Ratio suatu bank dapat diukur dengan rumus sebagai berikut (Dendawijaya, 2009:144):

$$
C A R=\frac{\text { Modal Bank }}{\text { Aktiva Tertimbang Menurut Risiko }} \times 100 \%
$$

Dimana:

Modal : Terdiri dari modal inti, modal pelengkap, dan modal pelengkap tambahan.

ATMR : Penanaman dana bank dalam bentuk saham pada perusahaan yang bergerak di bidang keuangan syariah atau jenis transaksi tertentu berdasarkan prinsip syariah yang berakibat bank memiliki atau akan memiliki saham pada perusahaan yang bergerak di bidang keuangan syariah.

Nilai kredit dihitung sebagai berikut:

Untuk CAR $=0 \%$ atau negatif, nilai kredit $=0$.

Untuk setiap kenaikan 0,1\%, nilai kredit ditambah 1 dengan maksimum 100.

\section{b) Asset (Kualitas Aset)}

Asset-aktiva adalah harta kekayaan yang berwujud nyata, seperti uang, bangunan, kantor atau benda lain yang dapat dinilai dengan uang maupun yang tidak berwujud nyata, seperti hak cipta. Semua pos pada sisi debet neraca yang terdiri atas harta, piutang, biaya yang dibayar terlebih dahulu, dan pendapatan yang akan diterima (Winarno dan Ismaya, 2003:47). 
Pada penilaian faktor kualitas aset yang digunakan adalah rasio NPA (Non Performing Asset). Rasio aktiva produktif bermasalah adalah rasio yang menunjukkan kemampuan manajemen bank dalam mengelola aktiva produktif bermasalah terhadap total aktiva produktif. Semakin tinggi rasio ini maka akan semakin buruk kualitas aktiva produktif yang menyebabkan Penyisihan Penghapusan Aktiva Produktif (PPAP) yang tersedia semakin besar maka kemungkinan suatu bank dalam kondisi bermasalah semakin besar.

Rasio ini dapat dirumuskan sebagai berikut:

$$
N P A=\frac{\text { Aktiva produktif Bermasalah }}{\text { Aktiva Produktif }}
$$

\section{c) Management (Manajemen)}

Manajemen dinilai atas kepatuhan Bank terhadap ketentuan Posisi Devisa Neto (PDN), yaitu selisih antara aktiva dan kewajiban dalam setiap mata uang asing yang semuanya dinyatakan dalam rupiah setelah memperhitungkan rekening administratif (Subawa dan Wiranti, 2013).

\section{d) Earning (Rentabilitas)}

Earning adalah seluruh pendapatan yang diperoleh atas berbagai faktor produksi, misalnya gaji, keuntungan, bunga dan sebagainya (Winarno dan Ismaya, 2003:169). Penilaian didasarkan pada rentabilitas suatu bank yang dilihat kemampuan suatu bank dalam menciptakan laba. Penilaian dalam unsur ini didasarkan kepada dua macam, yaitu (Kasmir, 2014:301):

\section{a. Rasio laba terdapat total asset (Return On Assets).}

$$
\text { ROA }=\frac{\text { Laba sebelum Pajak }}{\text { Total Aktiva }} \times 100 \%
$$

Dimana :

Laba : Keuntungan yang diterima dalam satu tahun.

Total Aktiva : Total aktiva baik lancar maupun tidak lancar.

Perhitungan kredit dilakukan sebagai berikut:

1). Untuk ROA sebesar $100 \%$ atau lebih, nilai kredit $=0$.

2). Untuk setiap kenaikan $0.015 \%$, nilai kredit ditambah 1 dengan maksimum 100.

b. Rasio Beban Operasional terhadap Pendapatan Operasional.

$$
\text { BOPO }=\frac{\text { Beban Operasional }}{\text { Pendapatan Operasional }} \times 100 \%
$$




\section{Dimana :}

Biaya operasional : Jumlah biaya umum, biaya administrasi, biaya gaji, dan tunjangan.

Pendapatan operasional : Pendapatan/beban bunga bersih dan pendapatan operasional lainnya.

Nilai kredit dapat dihitung, sebagai berikut:

a) Untuk rasio $100 \%$ atau lebih, nilai kredit $=0$.

b) Untuk setiap penurunan $0.08 \%$, nilai kredit ditambah 1 dengan maksimum 100.

\section{e) Liquidity (Likuiditas)}

Liquidity adalah kemampuan perusahaan untuk memenuhi kewajiban atau membayar utangnya pada asset pembayaran. Likuiditas bank yaitu kemampuan bank untuk membayar seluruh utang jangka pendek yang telah jatuh tempo (Winarno dan Ismaya, 2003:288). Dalam penelitian ini, proksi dari liquidity adalah FDR (Financing to Deposit Ratio). Semakin tinggi atau besar dana masyarakat yang dapat dihimpun oleh perbankan dan disalurkan dalam bentuk pembiayaan secara tepat, efisien dan hati-hati maka akan meningkatkan pendapatan perbankan.

$$
F D R=\frac{\text { Jumlah Kredit yang Diberikan }}{\text { Total Dana Pihak Ketiga }}
$$

\section{c. Kinerja Keuangan}

Kinerja (performance) dalam kamus istilah akuntansi adalah kuantifikasi dari keefektifan dalam pengoperasian bisnis selama periode tertentu. Kinerja keuangan adalah gambaran kondisi keuangan perusahaan pada suatu periode tertentu, baik menyangkut aspek penghimpunan dana maupun penyaluran dana, yang biasanya diukur dengan indikator kecukupan modal, likuiditas, dan profitabilitas.

Kinerja keuangan adalah suatu analisis yang dilakukan untuk melihat sejauh mana suatu perusahaan telah melaksanakan dengan menggunakan aturan-aturan pelaksanaan keuangan secara baik dan benar. Kinerja bank secara umum merupakan gambaran prestasi yang dicapai oleh bank dalam operasionalnya. Kinerja keuangan bank merupakan gambaran kondisi keuangan bank pada suatu periode tertentu baik mencakup aspek penghimpunan dana maupun penyaluran dananya. 


\section{d. Bank}

Lembaga keuangan mempunyai fungsi yang sangat mendukung terhadap pembangunan ekonomi suatu negara. Bank diartikan sebagai lembaga keuangan yang kegiatan utamanya adalah menghimpun dana dari masyarakat dan menyalurkannya kembali dana tersebut ke masyarakat serta memberikan jasa bank lainnya, sedangkan pengertian lembaga keuangan adalah setiap perusahaan yang bergerak di bidang keuangan di mana kegiatannya baik hanya menghimpun dana, atau hanya menyalurkan dana atau kedua-duanya menghimpun dan menyalurkan dana (Kasmir, 2008:11).

Bank konvensional adalah bank umum yang beroperasi dengan prinsip konvensional. Prinsip konvensional menggunakan metode menetapkan bunga sebagai harga jual. Bank syariah adalah bank yang menjalankan kegiatan usahanya berdasarkan prinsip syariah dan menurut jenisnya terdiri atas bank umum syariah dan bank pembiayaan rakyat syariah (Undang-undang No. 21 Tahun 2008). Bank syariah yaitu lembaga intermediasi dan penyediaan jasa keuangan yang bekerja berdasarkan etika dan sistem islam, khususnya yang bebas dari kegiatan spekulatif yang nonproduktif (Ascarya, 2005:4).

Bank syariah merupakan bank yang kegiatannya mengacu pada hukum Islam, dan dalam kegiatannya tidak membebankan bunga maupun tidak membayar bunga kepada nasabah. Imbalan yang diterima bank syariah maupun yang dibayarkan kepada nasabah tergantung dari akad dan perjanjian antara nasabah dan bank. Perjanjian (akad) yang ada pada perbankan syariah harus tunduk pada syarat dan rukun akad sebagaimana diatur dalam syariat Islam (Ismail 2011: 32).

Menurut Muhammad Syafi'i Antonio dalam (Hendro 2014: 183) terdapat 4 fungsi utama bank Syariah, yaitu : Pertama, manajemen Investasi, yaitu bank syariah melaksanakan fungsi ini berdasarkan kontrak mudharabah atau kontrak perwakilan. Menurut kontrak mudharabah, bank dalam kapasitasnya sebagai mudharib (pengelola dana), yaitu pihak yang melaksanakan investasi dana dari pihak lain akan menerima persentase keuntungan jika nasabah memperoleh laba.

Kedua, investasi, dimana bank syariah menginvestasikan dana yang ditempatkan pada dunia usaha (baik dana modal maupun dana rekening investasi) dengan menggunakan instrumen investasi yang sesuai dengan prinsip syariah, misal: kontrak murabahah, musyarakah, bai' as-salam, bai' al-istisna', dan ijarah. 
Ketiga, jasa keuangan, yaitu bank syariah dapat memberikan layanan berdasarkan fee pada sebuah kontrak perwakilan atau penyewaan, seperti garansi, transfer kawat, L/C. Keempat, kegiatan sosial dimana dalam prinsip syariah, seharusnya bank juga berfungsi sosial, seperti dana qardh (pinjaman kebaikan), zakat, atau pemberian dana sosial.

\section{METODE PENELITIAN}

Ruang lingkup penelitian ini meliputi menganalisis kinerja keuangan PT. Bank Muamalat Indonesia Tbk. Data adalah segala keterangan (informasi) mengenai semua halyang berkaitan dengan tujuan penelitian. Sumber data adalah subjek dari mana data dapat diperoleh. Data yang digunakan dalam penelitian ini meliputi data keuangan tahunan yang dipublikasikan PT. Bank Muamalat Indonesia Tbk dari tahun 2016 sampai 2018.

Penelitian ini menurut analisis datanya merupakan penelitian kuantitatif yaitu penelitian yang menganalisis data yang berbentuk angka. Sedangkan menurut kegunaannya, penelitian ini merupakan penelitian deskriptif yaitu penelitian yang hendak menggambarkan suatu keadaan, peristiwa atau gejala secara sistematis, faktual dengan penyusunan yang akurat.

Teknik analisis data yang digunakan dalam penelitian ini adalah dengan menggunakan analisis CAMEL. Berdasarkan penjelasan surat edaran Bank Indonesia analisis CAMEL dilakukan dengan langkah-langkah sebagai berikut:

1) Melakukan data review laporan keuangan (Neraca dan Laporan Laba Rugi) dengan sistem akuntansi yang berlaku maupun penjelasan lain yang mendukung.

2) Menghitung angka rasio masing-masing aspek CAMEL.

3) Menghitung nilai kotor masing-masing rasio.

4) Menghitung nilai bersih masing-masing rasio dengan jalan mengalikan nilai kotor masing-masing dengan standar bobot masing-masing rasio.

5) Menjumlahkan nilai bersih rasio CAMEL

6) Membandingkan hasil penjumlahan keseluruhan rasio CAMEL dengan standar Bank Indonesia.

Kriteria Penilaian

a. Capital (Permodalan) 
Berdasarkan pada matriks kriteria peringkat permodalan pada Surat Edaran Bank Indonesia No. 6/23/DPNP tanggal 31 Mei 2004 diperoleh standar untuk KPMM sebagai berikut:

Tabel Matriks kriteria Penetapan Peringkat Faktor Permodalan CAR

b. Asset

\begin{tabular}{|c|l|l|}
\hline Peringkat & Keterangan & Kriteria \\
\hline 1 & Sangat Sehat & KPMM $>15 \%$ \\
\hline 2 & Sehat & $9 \%<\mathrm{KPMM} \leq 15 \%$ \\
\hline 3 & Cukup sehat & $8 \%<\mathrm{KPMM} \leq 9 \%$ \\
\hline 4 & Kurang Sehat & $\mathrm{KPMM} \leq 8 \%$ \\
\hline 5 & Tidak Sehat & $\mathrm{KPMM}<8 \%$ \\
\hline
\end{tabular}

Berdasarkan pada matriks kriteria penetapan peringkat faktor kualitas aset pada Surat Edaran Bank Indonesia Nomor 6/23/DPNP tanggal 31 Mei 2004 diperoleh standar NPA sebagai berikut:

Tabel Matriks Kriteria Penetapan Peringkat Faktor Asset

\begin{tabular}{|c|c|l|}
\hline Peringkat & Keterangan & \multicolumn{1}{|c|}{ Kriteria } \\
\hline 1 & Sangat Sehat & Rasio 0\% sampai dengan 3\% \\
\hline 2 & Sehat & Rasio 3,01\%-5\% \\
\hline 3 & Cukup Sehat & Rasio 5,01\%-8\% \\
\hline 4 & Kurang Sehat & Rasio 8,01\%-10\% \\
\hline 5 & Tidak Sehat & Rasio diatas $10 \%$ \\
\hline
\end{tabular}

c. Management

Menurut Peraturan Bank Indonesia Nomor 6/20/PBI/2004 tanggal 15 Juli 2004 dan Nomor 7/37/PBI/2005 tanggal 30 September 2005 tentang posisi Devisa Neto Bank Umum, bank wajib memelihara PDN setinggi-tingginya 20\% dari modal.

Tabel Matriks Kriteria Peringkat Komponen Manajemen (Kepatuhan terhadap PDN)

\begin{tabular}{|c|c|l|}
\hline Peringkat & Keterangan & \multicolumn{1}{|c|}{ Kriteria } \\
\hline 1 & Sangat Sehat & Tidak ada pelanggaran rasio PDN \\
\hline 2 & Sehat & $\begin{array}{l}\text { Tidak ada pelanggaran rasio PDN } \\
\text { namun pernah melakukan pelanggaran }\end{array}$ \\
\hline
\end{tabular}




\section{d. Earning (Rentabilitas)}

\begin{tabular}{|c|c|l|}
\hline & & dan telah diselesaikan \\
\hline 3 & Cukup Sehat & $0 \%<$ Pelanggaran PDN $<10 \%$ \\
\hline 4 & Kurang Sehat & $10 \%<$ Pelanggaran rasio PDN $<25 \%$ \\
\hline 5 & Tidak Sehat & Pelanggaran PDN $>25 \%$ \\
\hline
\end{tabular}

Berdasarkan pada matriks kriteria penetapan peringkat faktor rentabilitas pada Surat Edaran Bank Indonesia No. 6/23/DPNP tanggal 31 Mei 2004 diperoleh standar ROA sebagai berikut:

Tabel Matriks Kriteria Penetapan Peringkat Komponen Rentabilitas (ROA)

\begin{tabular}{|c|c|c|}
\hline Peringkat & Keterangan & Kriteria \\
\hline 1 & Sangat Sehat & Rasio ROA diatas 2\% \\
\hline 2 & Sehat & Rasio ROA berkisar 1,26\%-2\% \\
\hline 3 & Cukup Sehat & Rasio ROA 0,51\%-1,25\% \\
\hline 4 & Kurang Sehat & Rasio berkisar 0\%-0,5\% \\
\hline 5 & Tidak Sehat & Rasio dibawah 0\% \\
\hline
\end{tabular}

Matriks Kriteria Penetapan Peringkat Komponen Rentabilitas BOPO

\begin{tabular}{|c|c|c|}
\hline Peringkat & Keterangan & Kriteria \\
\hline 1 & Sangat Sehat & Rasio berkisar $83 \%-88 \%$ \\
\hline 2 & Sehat & Rasio berkisar $89 \%-93 \%$ \\
\hline 3 & Cukup Sehat & Rasio berkisar $94 \%-96 \%$ \\
\hline 4 & Kurang Sehat & Rasio berkisar 97\%-100\% \\
\hline 5 & Tidak Sehat & Rasio diatas $100 \%$ \\
\hline
\end{tabular}

e. Likuiditas

Berdasarkan pada matriks kriteria penetapan peringkat faktor rentabilitas pada Surat Edaran Bank Indonesia No. 6/23/DPNP tanggal 31 Mei 2004 diperoleh standar untuk rasio FDR sebagai berikut: 
Tabel Matriks Kriteria Penetapan Peringkat Komponen Likuiditas FDR

\begin{tabular}{|c|c|c|}
\hline Peringkat & Keterangan & Kriteria \\
\hline 1 & Sangat Sehat & $50 \%<$ Rasio $\leq 75 \%$ \\
\hline 2 & Sehat & $75 \%<$ Rasio $\leq 85 \%$ \\
\hline 3 & Cukup Sehat & $85 \%<$ Rasio $\leq 100 \%$ \\
\hline 4 & Kurang Sehat & $100 \%<$ Rasio $\leq 120 \%$ \\
\hline 5 & Tidak sehat & Rasio $>120 \%$ \\
\hline
\end{tabular}

\section{Gambaran Umum PT. Bank Muamalat Indonesia Tbk}

PT Bank Muamalat Indonesia Tbk ("Bank Muamalat Indonesia") memulai perjalanan bisnisnya sebagai Bank Syariah pertama di Indonesia pada 1 November 1991 atau 24 Rabi'us Tsani 1412 H. Pendirian Bank Muamalat Indonesia digagas oleh Majelis Ulama Indonesia (MUI), Ikatan Cendekiawan Muslim Indonesia (ICMI) dan pengusaha muslim yang kemudian mendapat dukungan dari Pemerintah Republik Indonesia.

Sejak tahun 2015, Bank Muamalat Indonesia bermetamorfosa untuk menjadi entitas yang semakin baik dan meraih pertumbuhan jangka panjang. Dengan strategi bisnis yang terarah Bank Muamalat Indonesia akan terus melaju mewujudkan visi menjadi "The Best Islamic Bank and Top 10 Bank in Indonesia with Strong Regional Presence".

\section{PEMBAHASAN}

Analisis kinerja keuangan PT. Bank Muamalat Indonesia Tbk dapat dinilai dari Lampiran 2a Surat Edaran Bank Indonesia No.6/23/DPNP 31 Mei 2004, maka dapat dikelompokkan tingkat kesehatan Bank Muamalat Indonesia Tbk dari masing-masing rasio antara lain:

\section{Capital (Permodalan) : CAR}

Risiko yang digunakan dalam perhitungan permodalan ialah Capital Adequacy Ratio (CAR) yaitu perbandingan jumlah modal dengan Aktiva Tertimbang Menurut Risiko (ATMR). Capital Adequacy Ratio (CAR) digunakan untuk menilai keamanan dan 
kesehatan bank dari sisi modal pemiliknya. Semakin tinggi CAR, maka semakin baik kinerja bank tersebut.

Tabel Tingkat Kesehatan Bank Muamalat Indonesia Menurut Rasio Permodalan CAR 2016-2018

\begin{tabular}{|c|c|c|c|}
\hline Tahun & Rasio & Peringkat & Keterangan \\
\hline 2016 & $12,74 \%$ & 2 & Sehat \\
\hline 2017 & $13,62 \%$ & 2 & Sehat \\
\hline 2018 & $12,34 \%$ & 2 & Sehat \\
\hline
\end{tabular}

Sumber : Data Diolah

Berdasarkan hasil perhitungan rasio permodalan pada tahun 2016 rasio yang dicapai Bank Muamalat Indonesia sebesar 12,74\% yang berarti Bank Muamalat Indonesia menyediakan $12,74 \%$ dari investasinya untuk setiap Aktiva Tertimbang Menurut Risiko (ATMR) sejumlah Rp100 maka Bank Muamalat Indonesia membiayai dengan modal sebesar 0,1274.

Artinya, hasil kinerja keuangan Bank Muamalat Indonesia Tbk ditinjau dari segi kapital, pada tahun 2016 rasio permodalan sesuai dengan kriteria peringkat kedua yang dikategorikan dalam kelompok sehat. Pada tahun 2017 rasio tercapai 13,62\% yang berarti Bank Muamalat Indonesia menyediakan 13,62\% dari investasinya untuk setiap Aktiva Tertimbang Menurut Risiko (ATMR) sejumlah Rp100 maka Bank Muamalat Indonesia membiayai dengan modal sebesar 0,1362.

Pada tahun 2017 rasio permodalan berada pada kriteria peringkat kedua dalam kategori sehat. Pada tahun 2018 rasio yang dicapai Bank Muamalat Indonesia sebesar 12,34\% yang berarti menyediakan 12,34\% dari investasinya untuk setiap ATMR sejumlah Rp100 maka Bank Muamalat Indonesia membiayai modal sebesar 0,1234. Pada tahun 2018 rasio permodalan sesuai dengan kriteria kedua dalam kelompok sehat.

Adanya persentasi yang fluktuatif menunjukkan adanya kenaikan sekaligus penurunan jumlah modal dan aktiva tertimbang menurut risiko namun tidak terlalu berbeda jauh dan masih tetap dalam kategori sehat pada PT. Bank Muamalat Indonesia Tbk. Indikator menunjukkan kelompok sehat ialah semakin besar rasio Capital Adequacy Ratio (CAR) yang dimiliki oleh suatu bank, maka akan semakin baik karena hal itu berarti bank mampu menyediakan modal dalam jumlah besar. 


\section{Asset : Non Performing Asset (NPA)}

Semakin tinggi rasio aktiva produktif bermasalah (NPA) maka akan semakin buruk kualitas aktiva produktif yang memungkinkan suatu bank dalam kondisi bermasalah semakin besar.

Tabel Tingkat Kesehatan Bank Muamalat Indonesia berdasarkan Rasio Aktiva Produktif Bermasalah (NPA)

\begin{tabular}{|c|c|c|c|}
\hline Tahun & Rasio & Peringkat & Keterangan \\
\hline 2016 & $3,34 \%$ & 2 & Sehat \\
\hline 2017 & $3,79 \%$ & 2 & Sehat \\
\hline 2018 & $2,74 \%$ & 1 & Sangat sehat \\
\hline
\end{tabular}

Sumber : Data Diolah

Berdasarkan hasil rasio aktiva produktif bermasalah di atas, hasil analisis kinerja keuangan Bank Muamalat Indonesia Tbk, dari sisi aset, diketahui bahwa pada tahun 2016 rasio sebesar 3,34\% yang berdasarkan matriks kriteria penilaian kesehatan bank berada di peringkat kedua yakni berkisar antara 3,01\%-5\% artinya bank dalam kondisi sehat.

Hal ini berarti bahwa setiap perubahan aktiva produktif bermasalah sebesar Rp100 akan menyebabkan perubahan aktiva produktif yang diklasifikasikan sebesar 0,334. Pada tahun 2017 rasio jumlah aktiva produktif bermasalah dibandingkan aktiva produktifnya sebesar 3,79\%. Hal ini berarti bahwa setiap perubahan aktiva produktif bermasalah sebesar Rp100 menyebabkan perubahan aktiva produktif yang diklasifikasikan sebesar 0,379.

Nilai rasio ini dalam kategori sehat. Pada tahun 2018 rasio jumlah aktiva produktif bermasalah sebesar 2,74\% yang artinya setiap perubahan aktiva produktif bermasalah sebesar Rp100 menyebabkan perubahan aktiva produktif yang diklasifikasikan sebesar 0,274. Nilai rasio ini dikategotikan dalam kondisi sangat sehat. Selama tiga tahun terjadi peningkatan peringkat kesehatan bank yang diawal pada dua tahun sebelumnya dalam kondisi sehat berubah menjadi sangat sehat.

\section{Management : PDN}

Penilaian manajemen dimaksudkan untuk menilai kemampuan manajerial untuk mengurus bank dalam menjalankan usaha sesuai prinsip manajemen umum, kecukupan manajemen resiko, dan kepatuhan bank terhadap ketentuan baik yang berkaitan 
dengan prinsip kehati-hatian maupun kepatuhan terhadap prinsip syariah dan komitmen kepada Bank Indonesia. Manajemen dinilai atas kepatuhan bank terhadap Posisi Devisa Neto (PDN), bank wajib memelihara PDN setinggi-tingginya 20\% dari modal.

Tabel Tingkat Kesehatan Bank Muamalat Indonesia berdasarkan Posisi Devisa Neto

\begin{tabular}{|l|l|l|l|}
\hline Tahun & Rasio & Peringkat & Keterangan \\
\hline 2016 & $0,18 \%$ & 3 & Cukup Sehat \\
\hline 2017 & $0,21 \%$ & 3 & Cukup Sehat \\
\hline 2018 & $0,40 \%$ & 3 & Cukup Sehat \\
\hline
\end{tabular}

Sumber : Data Diolah

Hasil kinerja keuangan PT Bank Muamalat Indonesia Tbk Dari tabel diatas dapat dilihat bahwa kepatuhan bank terhadap posisi devisa neto selama tahun 2016-2018 mengalami peningkatan secara signifikan namun masih tetap pada peringkat ketiga dalam kategori cukup sehat. Dikatakan cukup sehat dikarenakan posisi devisa neto berada pada kisaran $0 \%<$ pelanggaran $\mathrm{PDN}<10 \%$.

\section{Earning}

Penilaian rentabilitas dimaksud untuk menilai kemampuan bank dalam menghasilkan laba terhadap aset yang dimiliki. Penilaian dari aspek rentabilitas ini dilakukan dengan Rasio Laba Terhadap Asset (ROA) dan perbandingan biaya operasi dan Pendapatan Operasi (BOPO).

\section{ROA}

ROA digunakan untuk mengukur kemampuan bank dalam menggunakan aset yang dimilikinya untuk menghasilkan laba kotor.

Tabel Tingkat Kesehatan Bank Muamalat Indonesia berdasarkan ROA

\begin{tabular}{|c|c|c|c|}
\hline Tahun & Rasio & Peringkat & Keterangan \\
\hline 2016 & $0,22 \%$ & 4 & Kurang Sehat \\
\hline 2017 & $0,11 \%$ & 4 & Kurang Sehat \\
\hline 2018 & $0,08 \%$ & 4 & Kurang Sehat \\
\hline
\end{tabular}

Dari tabel diatas diketahui bahwa ROA pada PT. Bank Muamalat Indonesia Tbk tahun 2016 sebesar 0,22\% artinya setiap Rp100 aset digunakan bank hanya mampu menghasilkan Rp0,0022 laba bersih bank hanya mampu menghasilkan 0,22\% dari total 
aset yang digunakan. Tahun 2017 rasio sebesar 0,11\% artinya setiap Rp100 aset yang digunakan hanya mampu menghasilkan Rp0,0011 laba bersih atau bank hanya mampu menghasilkan 0,11\% dari total aset yang digunakan.

Tahun 2018 rasio sebesar 0,08\% artinya setiap Rp100 aset yang digunakan hanya menghasilkan Rp0,0008 laba bersih atau bank hanya mampu menghasilkan 0,08\% dari total aset yang digunakan. Dari tahun 2016 sampai tahun 2018 dilihat bahwa rasio ROA terus mengalami penurunan dan berada pada peringkat keempat dalam kategori kurang sehat. Hal ini menunjukkan bahwa tingkat efisiensi pengelolaan bank kurang baik sehingga laba yang dihasilkan kurang baik.

\section{BOPO}

Rasio BOPO digunakan untuk mengukur tingkat efisiensi dan kemampuan bank dalam melakukan kegiatan operasinya. Semakin kecil rasio BOPO berarti semakin efisien biaya operasional yang dikeluarkan Bank Muamalat Indonesia sehingga kemungkinan bank bermasalah semakin kecil.

Tabel Tingkat Kesehatan Bank Muamalat Indonesia berdasarkan Rasio BOPO

\begin{tabular}{|c|c|c|c|}
\hline Tahun & Rasio & Peringkat & Keterangan \\
\hline 2016 & $97,76 \%$ & 4 & Kurang Sehat \\
\hline 2017 & $97,68 \%$ & 4 & Kurang Sehat \\
\hline 2018 & $98,24 \%$ & 4 & Kurang Sehat \\
\hline
\end{tabular}

Dari tabel diatas dapat dilihat bahwa rasio BOPO pada PT Bank Muamalat Indonesia Tbk dari tahun 2016 sampai tahun 2018 memiliki tren fluktuatif. Pada tahun 2016 rasio sebesar 97,76\% artinya setiap Rp100 pendapatan operasional menggunakan beban operasional sebesar Rp0,9776. Pada tahun 2017 rasio sebesar 97,68\% artinya setiap Rp100 pendapatan operasional menggunakan beban operasional sebesar Rp0,9768.

Pada tahun 2018 rasio sebesar 98,24\% artinya setiap Rp100 pendapatan operasional menggunakan beban operasional sebesar Rp0,9824. Sehingga terjadi penurunan dan peningkatan di tahun 2017 dan tahun 2016. Namun kondisi kesehatan bank tetap dalam peringkat keempat dalam kategori kurang sehat. 


\section{Likuiditas : FDR}

Likuiditas adalah kemampuan untuk membayar kewajiban finansial jangka pendek tepat pada waktunya yang ditunjukkan oleh besar kecilnya aset lancar Semakin tinggi rasio FDR menunjukkan semakin rendah kemampuan likuiditas Bank Muamalat Indonesia.

Tabel Tingkat Kesehatan Bank Muamalat Indonesia berdasarkan Rasio FDR

\begin{tabular}{|c|c|c|c|}
\hline Tahun & Rasio & Peringkat & Keterangan \\
\hline 2016 & $95,13 \%$ & 3 & Cukup Sehat \\
\hline 2017 & $84,41 \%$ & 2 & Sehat \\
\hline 2018 & $73,18 \%$ & 1 & Sangat Sehat \\
\hline
\end{tabular}

Dari tabel diatas dapat dilihat bahwa pembiayaan terhadap dana pihak ketiga (FDR) pada PT Bank Muamalat Indonesia Tbk tahun 2016 sebesar 95,13\% yang menunjukkan kesehatan bank dalam peringkat ketiga dalam kategori cukup sehat. Pada tahun 2017 rasio mengalami penurunan yakni menjadi 84,41\% pada peringkat kedua dalam kategori sehat.

Pada tahun 2018 rasio kembali mengalami penurunan pada angka 73,18\% yakni berada pada peringkat pertama dalam kategori sangat sehat. Persentase dari rasio ini menunjukkan besarnya kewajiban bersih call money terhadap aset lancar atau aset yang paling likuid dari bank. Semakin kecil rasio ini, maka likuiditas bank ini semakin baik karena bank dapat menutup kewajiban antar bank dengan alat likuid yang dimilikinya.

Semakin menurunnya rasio FDR dari tahun ke tahun merupakan sesuatu yang sangat baik. Artinya kemampuan bank dalam melakukan pembiayaan baik (kemampuan likuiditas bank untuk mengantisipasi kebutuhan likuiditas dan penerapan manajemen likuiditas kuat).

\section{KESIMPULAN}

Hasil analisis kinerja keuangan tahun 2016-2018 pada PT. Bank Muamalat Indonesia Tbk ditinjau dari segi capital yang ditinjau dari Capital Adequacy Ratio (CAR) dalam kondisi sehat. Dari segi asset yang dinilai dari Non Performing Asset (NPA) pada tahun 2016 dan 2017 PT. Bank Muamalat Indonesia Tbk dalam kondisi sehat dan tahun 2018 dalam kondisi sangat sehat.

Dari segi manajemen yang diukur melalui Posisi Devisa Neto (PDN) mulai tahun 2016 sampai tahun 2018 tetap dalam kondisi cukup sehat. Dari segi Earning atau 
rentabilitas ditinjau dengan Return On Asset (ROA) dihasilkan mulai tahun 2016 sampai tahun 2018 dalam kondisi keempat dalam kategori kurang sehat.

Rentabilitas juga ditinjau dari rasio BOPO dihasilkan pula dari tahun 2016 sampai 2018 dalam kondisi kurang sehat. Dari segi likuiditas dinilai dari segi Financing Deposit Ratio (FDR) pada tahun 2016 dalam kategori cukup sehat, tahun 2017 dalam kategori sehat dan tahun 2018 dalam kategori sangat sehat.

\section{SARAN}

Kondisi kinerja keuangan pada PT Bank Muamalah Tbk dalam keadaan yang berbeda-beda namun yang paling mengkhawatirkan pada rentabilitas yakni dengan rasio ROA dan BOPO karena rentablitas pada PT Bank Muamalat Indonesia Tbk dalam kondisi kurang sehat. Tidak hanya itu, perlu juga diperhatikan dari sisi manajemen dalam kategori cukup sehat agar lebih diringkatkan menjadi sehat.

Keterbatasan penelitian ini hanya pada PT Bank Muamalat Indonesia Tbk, untuk selanjutnya bisa pada bank syariah lainnya.

\section{DAFTAR PUSTAKA}

Bank Indonesia. (2004). Peraturan Bank Indonesia No.6/10/PBI/2004 Tentang Sistem Penilaian Tingkat Kesehatan Bank Umum. Jakarta.

Bank Indonesia. 2011. Peraturan Bank Indonesia Nomor 13/1/PBI/2011 Tentang Tata Cara Penilaian Kesehatan Bank Umum.

Hendro. (2014). -Bank Umum Syariah.|| In Bank Dan Insititusi Keuangan Non Bank Di Indonesia, edited by UPP STIM YKPN, 1sted., 181. Yogyakarta: UPP STIM YKPN.

Ikatan Akuntan Indonesia. (2002). Kerangka Dasar Penyusunan dan Penyajian Laporan Keuangan Bank Syari'ah. Jakarta: IAI.

Ismail. (2011). -Konsep Dasar Bank Syariah.\| In Perbankan Syariah, edited by Kharisma Putra Utama, 1sted. jakarta: Kencana Prenadamedia Group.

Kasmir. (2008). Bank dan Lembaga Keuangan Lainnya. Edisi Revisi 2008. Jakarta: PT. Raja Grafindo Persada.

Kusumo, Yunanto Adi. (2008). Analisis Kinerja Keuangan Bank Syariah Mandiri periode 2002-2007 (dengan Pendekatan PBI No.9/1/PBI/2007). 
Marlyna. Diana, Mohan Aka Wirando. (2018). Analisa Tingkat kesehatan Bank Syariah. Technobiz : International Journal of Business, Vol. 1, No. 1, 2018, 19-24. E-ISSN 2655-3457

M. Syafi'i Antonio. (2001). Bank Syariah: Dari Teori ke Praktik. Jakarta: Gema Insani Press.

Muhammad. (2002). Manajemen Bank Syari'ah. Yogyakarta: UPP AMP YKPN.

Munawir (2001). Analisa Laporan Keuangan. Yogyakarta: Liberty.

Otoritas Jasa Keuangan. 2014. Peraturan Otoritas Jasa Keuangan Nomor 8/POJK.03/2014 Tentang Penilaian Tingkat Kesehatan Bank Umum Syariah dan Unit Usaha Syariah.

Sari, Arnita. (2018). Analisis Kinerja Keuangan Bank Syariah (Studi Kasus Bank Syariah Mandiri, Tbk tahun 2015-2017). Universitas Negeri Yogyakarta.

Sugema, I., dkk. 2004. Bank BRI Keluar dari Krisis. Dari Restrukturisasi sampai IPO.INDEF, Jakarta.

www.bankmuamalat.co.id 